\title{
KECAKAPAN BERKOMUNIKASI BERBASIS ENGLISH FOR TOURISM BERMUATAN KEARIFAN LOKAL MASYARAKAT KAVLING SEROJA KOTA BATAM
}

\author{
Yunisa Oktavia $^{1 *}$, Nur Elfi Husda ${ }^{1}$, Suhardianto ${ }^{1}$ \\ Program Studi Sastra Inggris, Fakultas Ilmu Sosial dan Humaniora, Universitas Putera Batam, Batam, Indonesia \\ *Penulis Korespodensi : yunisaoctavia@gmail.com
}

\begin{abstract}
Abstrak
Kegiatan pengabdian kepada masyarakat ini dilatarbelakangi oleh (1) kecakapan berkomunikasi masyarakat belum mampu memberikan pelayanan kepada turis apabila berkunjung ke Kota Batam, (2) kemahiran berbahasa Inggris berbasis English for tourism masyarakat belum optimal, (3) melestarikan nilai-nilai kearifan lokal di tengah kehidupan masyarakat di ranah Melayu yang memiliki nilai keberagaman budaya daerah, dan (4)meningkatkan pengetahuan English for tourism masyarakat Kavling Seroja. Tujuan kegiatan pengabdian kepada masyarakat adalah untuk meningkatkan kecakapan berkomunikasi berbasis English for tourism bermuatan kearifan lokal masyarakat Kavling Seroja Kota Batam. Peserta pengabdian adalah ibu rumah tangga warga Kavling Seroja Kota Batam. Metode pelaksanaan terdiri atas tahap prencanaan, pelaksanaan, dan evaluasi. Hasil kegiatan menunjukkan bahwa tim pengabdi berupaya untuk memberikan pengetahuan kepada masyarakat agar mahir berbahasa Inggris dan bisa mengelola bidang pariwisata di dekat tempat tinggalnya. Peserta pengabdian menghadiri kegiatan pengabdian ini dengan antusias dan penuh semangat. Peserta diberikan materi petunjuk jalan, lokasi objek wisata, pusat perbelanjaan, kuliner tanah Melayu, rumah sakit, dan perbankan yang dibutuhkan oleh turis. Saat praktik penggunaan English for tourism peserta mahir menggunakan bahasa Inggris. Inovasi dari hasil kegiatan pengabdian ini adalah masyarakat Kavling Seroja memiliki kemahiran English for tourism dan enterpreneurship berbasis kearifan lokal setelah kegiatan PKM dilaksanakan.
\end{abstract}

Kata kunci: English for Tourism; Enterpreneurship; Kearifan Lokal; Kecakapan Berkomunikasi.

\begin{abstract}
Community service activities are motivated by (1) communication skills of the community have not been able to provide services to tourists when visiting Batam City, (2) English-language proficiency based on English for tourism is not yet optimal, (3) preserving the values of local wisdom in the midst of community life in the Malay realm which has the value of regional cultural diversity, and (4) increase knowledge of English for tourism of the Kavling Seroja community. The purpose of community service activities is to improve communication skills based on English for tourism containing local wisdom Kavling Seroja people in Batam. The participants of the service are housewives in the Kavling Seroja Batam City. The implementation method consists of the planning, implementation and evaluation stages. The results of the activity show that the service team seeks to provide knowledge to the community so that they are proficient in English and can manage the field of tourism near where they live. Devotion participants attend these devotion activities with enthusiasm and motived. Participants were given materials on directions, locations of attractions, shopping centers, culinary Malay land, hospitals, and banking needed by tourists. When practicing the use of English for tourism participants are proficient in using English. Innovation from the results of this community service activity is that the people of Kavling Seroja have the expertise in English for tourism and entrepreneurship based on local wisdom after the PKM activities are carried out.
\end{abstract}

Keywords: English for Tourism; Enterpreneurship; Local Wisdom; Communication Skills.

\section{PENDAHULUAN}

Dalam kegiatan berkomunikasi, setiap warga masyarakat memerlukan kecakapan berkomunikasi yang efektif sebagai sarana untuk bisa berinteraksi. Interaksi akan terlaksana apabila masyarakat memiliki pemahaman yang sama akan bahasa yang digunakan.
Namun, kenyataannya masyarakat di Kecamatan Sagulung belum terlatih menggunakan bahasa Inggris sebagai bahasa kedua di Indonesia. Sejalan dengan itu, terdapat hasil penelitian Tölkes (2018) bahwa kemampuan berkomunikasi dan kemahiran berbahasa Inggris harus dimiliki oleh setiap individu agar dapat 
mendukung kegiatan pariwisata. Selanjutnya, untuk mendukung program pemerintahan Kota Batam bahwasanya Batam menjadi daerah yang berorientasi pada kota pariwisata, perlu diciptakan industri kreatif di tengah-tengah kehidupan masyarakat untuk meningkatkan taraf ekonomi masyarakat. Di samping itu, perlu diintegrasikan kearifan lokal sebagai hasil dari masyarakat tertentu melalui pengalaman akan budaya tersendiri untuk bisa dilestarikan. Nilai-nilai kearifan lokal akan melekat sangat kuat pada masyarakat tertentu apabila direalisasikan.

Kecakapan berkomunikasi ini dijadikan sebagai modal dasar bagi masyarakat agar melestarikan bahasa daerah, mengutamakan bahasa Indonesia, dan menguasai bahasa asing. Bahasa asing yang dimaksud adalah penguasaan bahasa Inggris bagi masyarakat setempat. Bahasa Inggris digadang-gadangkan sebagai bahasa internasional agar masyarakat mampu berdaya saing secara internasional. Bahasa Inggris menjadi bahasa kedua bagi masyarakat di Indonesia pada masa ini. Bahakan berbagai lembaga, komunitas, dan sebagian lapisan masyarakat. Masyarakat ingin mahir berbahasa Inggris namun terkendala dengan berbagai keterbatasan baik itu kesempatan maupun biaya yang harus dikeluarkan. Apalagi era MEA, bahasa Inggris dijadikan sebagai bahasa utama setelah bahasa Indonesia.

Kearifan lokal merupakan suatu kebijakan berdasarkan hasil kesepakatan suatu masyarakat lokal atau kolektif tertentu untuk mengatur kehidupan yang berkaitan dengan keyakinan (agama), hubungan sosial, pendidikan, dan norma. Kearifan lokal berfungsi sebagai kontrol sosial di masyarakat yang diwariskan secara turun temurun melalui tradisi sehingga kebudayaan itu tetap melekat dan menjadi karakter masyarakatnya. Nilai-nilai kearifan lokal itu antara lain: (1) nilai-nilai kearifan lokal sebagai fungsi penebal keyakinan dan mengembangkan integritas masyarakat; (2) nilai-nilai kearifan lokal sebagai fungsi tunjuk ajar pendidikan dan alat kontrol sosial; (3) nilai-nilai kearifan lokal sebagai fungsi solidaritas sosial memadukan kekuatan kebersamaan yang terpecah; (4) nilai-nilai kearifan lokal sebagai fungsi identitas kelompok (kolektif); dan (5) nilai-nilai kearifan lokal sebagai fungsi harmonisasi komunal.

Hastuti (2013) mengemukakan bahwa kearifan lokal merupakan suatu kebiasaan yang menjadi tradisi masyarakat yang diwariskan secara turun menurun oleh adat daerah di erbagai wilayah. Provinsi Sumatera Barat atau dikenal dengan nama Ranah Minang, memiliki beberapa jenis kearifan lokal sosial budaya yang berkaitan dengan seluruh sumber daya yang ada. Masyarakat Minangkabau sebagai salah satu suku etnis yang ada di Indonesia memiliki sejumlah nilai-nilai moral sosial budaya yang terdapat dalam wujud kebudayaan Minangkabau.

Pendekatan yang digunakan untuk menyelesaikan persoalan mitra adalah pendekatan secara langsung artinya adalah tim pengabdi langsung mengayomi dan membina masyarakat selama lima kali pertemuan yang dimulai dari bulan Juli sampai Agustus 2019. Kegiatan pengabdian tidak mengganggu kegiatan rumah tangga ibu-ibu rumah tangga yang menjadi peserta pengabdian. Kegiatan pengabdian ini berujuan untuk menyelesaikan persoalan dan permalahan yang dihadapi masyarakat yang berkaiatan dengan kecakapan berkomunikasi berbasis English for tourism dan enterpreneurship bagi masyarakat Kavling Bukit Seroja. Kegiatan pengabdian penting dan patut untuk dilaksanakan agar masyarakat setempat memiliki usaha kreatif secara mandiri sehingga membantu perekonomian masyarakat.

Jeniarto (2013) menyatakan bahwa secara garis besar diandaikan terdapat dua pemaknaan kearifan lokal (Local Wisdom). Pertama, Local Wisdom dimaknai sebagai pengetahuan warisan leluhur yang diturunkan melalui tradisi. Pengetahuan ini bersifat permanen di dalam berbagai era. Kedua, Local Wisdom apat menghadapi persoalan hidup. Pengetahuan ini senantiasa berubah sesuai lingkungan jaman. Pengetahuan ini bersifat kontekstual di dalam ruang dan waktu yang berbeda. Selain itu, diperkuat oleh hasil penelitian [4] Leksono, Rustaman, \& Redjeki (2015) bahwa selama perkuliahan berlangsung seorang dosen bertujuan untuk menggali kearifan lokal. Kearifan lokal sebagai ilmu pengetahuan suatu komunitas secara berabad-abad berdasarkan pengalaman, telah diuji penggunaannya, sudah diadaptasikan dengan budaya serta bersifat dinamis.

Kearifan lokal adalah pandangan hidup dan ilmu pengetahuan serta berbagai strategi kehidupan yang berwujud aktivitas yang dilakukan oleh masyarakat lokal dalam menjawab berbagai masalah dalam pemenuhan kebutuhan mereka. Dalam bahasa asing sering juga dikonsepsikan sebagai kebijakan setempat local wisdom atau pengetahuan setempat local knowledge atau kecerdasan setempat local genious (Fajarini, 2014). Berbagai strategi dilakukan oleh masyarakat setempat untuk menjaga kebudayaannya.

Berdasarkan solusi yang ditawarkan, terdapat hasil riset tim pengabdi Oktavia \& Hulu (2017) .Hasil riset tim pengabdi terkait dengan solusi yang ditawarkan agar membudayakan kearifan lokal kepada masyarakat. Kearifan lokal yang dimaksud adalah membudayakan karakter dan kepribadian budaya Melayu, mengatur kehidupan yang berkaitan dengan keyakinan (agama), hubungan sosial, pendidikan, dan norma. Kearifan lokal berfungsi sebagai kontrol sosial di masyarakat yang diwariskan secara turun temurun melalui tradisi sehingga kebudayaan itu tetap melekat dan menjadi karakter masyarakatnya. 


\begin{tabular}{|c|c|}
\hline Nama RT dalam RW 07 & Jumlah KK \\
\hline RT 01 & 100 \\
\hline RT 02 & 95 \\
\hline RT 03 & 80 \\
\hline RT 04 & 100 \\
\hline RT 05 & 45 \\
\hline
\end{tabular}

(Sumber:Data RW 07 Kelurahan Sei. Pelunggut Kecamatan Sagulung Kota Batam)

Permasalahan yang ditemui adalah (1) masyarakat belum mahir menggunakan bahasa Inggris. Padahal daerah di sekitar tempat tinggal masyarakat berpotensi untuk dikunjungi oleh turis. Hal tersebut menjadi kendala bagi mereka dalam mengembangkan diri dan melayani turis yang datang. Berdasarkan permasalahan tersebut, tim pengabdi berupaya untuk memberikan pengetahuan kepada masyarakat agar mahir berbahasa Inggris dan bisa mengelola bidang pariwisata di dekat tempat tinggalnya. (2) Masyarakat setempat belum memiliki kemahiran dalam mengelola aset dan talenta yang dimiliki untuk bisa dijadikan sebagai usaha enterpreneur yang kreatif. Padahal menjadi peluang besar bagi masyarakat dalam meningkatkan taraf perekonomian keluarganya. Jumlah KK sebanyak 420 KK. (3) Masyarakat yang khususnya ibu-ibu rumah tangga belum memiliki jiwa kreatif untuk membuka usaha berdasarkan keahlian dan keterampilan yang dimilikinya. Padahal, berdasarkan hasil survei dan wawancara ke lokasi pengabdian, masyarakat tersebut mengakui pandai membuat kue, snack, cemilan, maupun keahlian menjahit, keset kaki, dan keahlian lainnya. Padahal itu menjadi aset bagi mereka untuk bisa maju dan berkembang di bagian wirausaha. Namun, dalam kegiatan pengabdian ini akan mengoptimalisasikan pembuatan keset kaki secara kreatif dan bernilai jual. Harga jual satu buah keset kaki Rp 12.000,00 s.d. Rp 15.000,00 dengan modal Rp 5.000,00 perlembar. (4) Masih minimnya peranan pihak terkait dan memiliki wewenang dalam mengembangkan kearifan lokal di Kota Batam. (5) Optimalisasi kearifan lokal belum dilaksanakan secara maksimal dalam masyarakat. Hal ini ditunjukkan sarana yang dimiliki belum mampu memiliki dan mengelola kearifan lokal. (6) Kreativitas masyarakat dalam mengelola dan mengembangkan aset daerah tempat tinggal masih terbatas. Oleh karena itu, diperlukan kegiatan pembinaan yang bertujuan untuk mengarahkan dan membina masyarakat setempat untuk bisa mandiri dan kreatif. (7) Masyarakat juga terkendala dengan dana untuk memulai usaha UKM. Hal ini menjadi urgen demi terlaksananya kegiatan pengabdian ini agar bisa berkembang di tangan masyarakat. Belum ada UMKM yang berdiri di Kavling Seroja.

Masyarakat belum mahir menggunakan bahasa Inggris. Padahal daerah di sekitar tempat tinggal masyarakat berpotensi untuk dikunjungi oleh turis. Hal tersebut menjadi kendala bagi mereka dalam mengembangkan diri dan melayani turis yang datang. Berdasarkan permasalahan tersebut, tim pengabdi berupaya untuk memberikan pengetahuan kepada masyarakat agar mahir berbahasa Inggris dan bisa mengelola bidang pariwisata di dekat tempat tinggalnya. Masyarakat yang mengikuti pelatihan selama lima kali pertemuan berjumlah 25 orang. Dari jumlah peserta pelatihan yang memiliki kompetensi dan kemahiran berbahasa Inggris sebanyak 17 orang secara fasih dan 8 orang lagi belum lancar. Pada awalnya hanya dua orang yang memiliki basic bahasa Inggris. Oleh karena itu,dengan adanya kegiatan pelatihan kemahiran berbahasa Inggris meningkatkan kompetensi masyarakata Kavling Seroja. Tujuan kegiatan pengabdian kepada masyarakat adalah (1) untuk memberikan pelatihan kepada warga Kavling Seroja untuk memiliki kecakapan berkomunikasi agar mahir berbahasa Inggris berbasis English for tourism, (2) untuk mengembangkan jiwa enterpreneurship masyarakat agar menjadi ibu rumah tangga yang mandiri dan kreatif. Masyarakat diajak dan diberikan motivasi agar memiliki kecakapan berkomunikasi dan kesantunan berbahasa saat berkomunikasi dan berinteraksi. Masyarakat bisa menghasilkan sabun cuci piring dan keset kaki, (3) masyarakat memiliki satu UMKM baru yang berada di Kavling Seroja sehingga bisa menghasilkan nilai ekonomi secara berkelanjutan.

\section{BAHAN DAN METODE}

Bahan yang digunakan dalam kegiatan pengabdian kepada masyarakat untuk pmebuatan sabun cuci piring dan keset kaki. Sabun cuci piring terbuat dari texapone, jeruk nipis, daun pandan, air, dan garam. Pada pembuatan keset kaki terbuat dari limbah atau perca kain yang dianyam menggunakan alat bernama mal.

Metode pelaksanaan dan analisis kegiatan pengabdian kepada masyarakat meliputi tahapan berikut. (1) Pemahaman konsep pentingnya English for tourism sebagai langkah awal masyarakat untuk bisa memiliki kreativitas dalam melayani turis asing apabila berkunjung ke tempat mereka. (2) Apabila masyarakat sudah memahami bahasa Inggris secara menyeluruh maka masyarakat sekitar bisa menjadi guided bagi turis yang berkunjung. (3) Selain itu, jika masyarakat sudah paham penggunaan bahasa Inggris, maka tim pengabdi mengarahkan agar mampu membuka tempat les atau privat bahasa Inggris di lokasi tempat tinggal mereka karena target sasarannya adalah ibu rumah tangga dalam usia produktif dan energik antara umur 20-40 tahun sehingga berpeluang untuk bisa membuka lokasi rumah belajar atau tempat privat. Tim pengabdi membantu dan berupaya untuk menguruskan surat izin dan administrasi. (4) Apabila lokasi les sudah ada maka tim pengabdi mengarahkan kepada ibu rumah tangga yang lain agar bisa membuka wirausaha dekat lokasi les dan lokasi pariwisata di Kota Batam. (5) Membina masyarakat agar mampu berwirausaha secara mandiri dengan mendayagukan keterampilan yang dimilikinya. (6) Mendorong masyarakat untuk mampu memasarkan hasil kreasinya dengan mendayagunakan IT yang sedang berkembang pesat. (7) Mendorong dan memberikan wawasan serta perkembangan ilmu bahasa kepada masyarakat. (8) Mengemukakan solusi secara 
variatif kepada peserta pembinaan tentang permasalahan yang dihadapi dari segi berbahasa.

\section{HASIL DAN PEMBAHASAN}

Untuk mendukung program pemerintah Kota Batam dalam menjadikan Kota Batam sebagai kota berbasis pariwisata, tim pengabdi berupaya memberikan pelatihan kepada masyarakat berupa ibu-ibu dan anakanak dalam kemahiran kecakapan berbahasa Inggris. Tim pengabdi menyampaikan kiat-kiat dan trik agar masyarakat Kavling Seroja mahir berbahasa Inggris. Tim pengabdi juga menyampaikan agar membiasakan berbahasa Inggris dalam kehidupan sehari-hari agar semakin lancar.

Pelaksanaan kegiatan pengabdian dilaksanakan selama lima kali pertemuan dan setelah itu melaksanakan survei kegiatan UMKM yang berhasil didirikan dan dirangkul oleh tim pelaksana. Hal ini menjadi hasil yang sangat luar biasa bagi tim pelaksana karena hasil kegiatan pengabdian ini memberikan dampak positif kepada masyarakat sehingga memiliki usaha yang mandiri, kreatif, dan tepat sasaran bagi warga sekitar. UMKM yang didirikan ini mengundang warga sekita Kavling Seroja menjadi pekerja yang diberdayakan sehingga dapat meningkatkan taraf ekonomi keluarga mereka. Sebelum kegiatan pengabdian dilaksanakan, tim pengabdi berdiskusi dengan pihak mitra yang dihadiri oleh RW dan perangkat RT Kavling Seroja. Mereka sangat antusias dengan kegaitan yang akan dilakukan karena tema kegiatan pengabdian ini sangat berterima oleh mereka sehingga bisa diberdayakan oleh warganya.

Dalam pelaksanaannya, tim pengabdi menyampaikan pentingnya kecakapan berkomunikasi berbasis kearifan lokal. Kearifan lokal menjadi payung agar tetap terus membudayakan budaya Melayu khas Kota Batam. Masyarakat Melayu yang terkenal dengan kearifan lokal adat bersandikan syarak, syarak bersandikan kitabullah, gurindam 12, patah tumbuh hilang berganti, di mana bumi dipijak, di sana langit dijunjung, dan berpancang amanah bersauh marwah. Kearifan lokal menjadi khazanah budaya yang terus dilestarikan dan dimaknai sehingga direalisasikan dalam kehidupan bermasyarakat. Walaupun masyarakat Kavling Seroja berasal dari daerah yang berbeda, tetapi tidak menyurutkan mereka untuk merealisasikan kearifan lokal budaya Melayu. Mereka tetap saling menjunjung tinggi keberagaman dan besatu dalam kegiatan sosial di lingkungan tenpat tinggalnya.

Kegiatan pengabdian ini dengan mengundang narasumber yang memiliki keahlian di bidangnya serta melibatkan mahasiswa. Mahasiswa yang dilibatkan sebnayak empat orang mahasiswa. Melibatkan mahasiswa agar mereka memiliki jiwa sosial dan mampu bersosialisasi bersama kehidupan masyarakat serta berbagi ilmu yang sudah diperolehnya selama di bangku perkuliahan. Melibatkan melaksanakan tugasnya sesuai dnegan uraian tugas yang sudah ditetapkan sehingga mahasiswa sudah memiliki kesadaran dan tanggung jawab akan amanah yang diberikan kepadanya. Dalam kegiatan survei, pihak mitra berjanji akan mengajak dan mengimbau masyarakat agar ikut serta dalam kegiatan ini. Di samping itu, pihak mitra juga memberikan saran dan arahan agar masyarakat Kavling Seroja dilatih secara maksimal agar mahir berbahasa Inggris dan memiliki jiwa enterpreneurship secara inovatif.

Pertemuan pertama, mengajak masyarakat agar mmapu berkomunikasi secara efektif. Hal ini bertujuan agar tidak terjadi kesalahpahaman dan memicu unsur SARA. Selainitu, dengan adanya pkegiatan pengabdian ini juga mengarahkan masyarakat agar mengikuti perkembangan Kota Batam berbasis kota pariwisata. Jika ada turis yang ada datang ke lokasi warga, ibu-ibu sudah bisa memberikan pelayanan kepada turis yang datang. Tim pengabdi mengajak agar peserta pengabdian mempersiapkan diri untuk bisa menghadapi arus globalisasi di tengah-tengah kehidupan masyarakat pada masa kini.

Pada pembahasan materi, tim pengabdi menyampaikan pentingnya kecakapan berkomunikasi secara santun dan berkarakter. Selain itu, tim pengabdi juga menyampaikan berbahasa Inggris pada Kota Pariwisata. Kita sebagai masyarakat harus siap menerima arus wisatawan mancanegara yang berkunjung ke daerah kita. Hal ini sangata diperlukan dukungan pemerintah bersama masyarakat agar terus menggalakkan English for tourism berbasis kearifan lokal. Selanjutnya juga untuk mengenalkan budaya Melayu berbasis kearifan lokal yang ada di Kota Batam kepada turis mancanegara yang berkunjung di Kota Batam sebagai destinasi kota wisata.

Narasumber kedua pada pertemuan tersebut menjelaskan teknik penggunaan bahasa Inggris secara mudah dan tegas. Teknik penguasaan English for tourism meliputi pengenalan terhadap suasana liburan, lokasi objek wisata yang ada di Batam, objek wisata yang bernilai sejarah, fasilitas yang disediakan, hotel terdekat dari objek wisata, makanan favorit dan makan khas daerah Melayu, pusat oleh-oleh, karier untuk turis, dan layanan rumah sakit maupun perbankan. Narasumber memberikan contoh agar bisa ditiru oleh peserta pengabdian. Kegiatan ini menjadi sangat menarik bagi ibu-ibu karena mereka harus belajar kembali penggunaan bahasa Inggris untuk wisata.

Peserta pengabdian juga bisa menyampaikannya kepada anak-anak mereka di rumah. Kegiatan ini sebagai wujud untuk menggalakkan English for tourism bagi semua lapisan masyarakat. Masyarakat diarahkan harus memiliki kesadaran dalam kecakapan berkomunikasi yang meliputi kecakapan berbicara, kecakapan bertanya, kecakapan menyimak, dan kecakapan menjawab pertanyaan orang lain. Masyarakat harus mampu berinteraksi secara efektif dengan lingkungan sekitar. Oleh karena itu, menjadi tujuan utama dan sasaran dalam kegiatan pengabdian ini. 
Kegiatan ini juga didukung oleh ahsil penelitian Oktavia dkk, (2019) bahwa masyarakat perlu dibina untuk mahair berbahasa Inggris dan bisa didukung dengan bantuan android. Pada pendayagunaan android bisa memanfaatkan aplikasi ID-ED translator yang dapat diakses dimanapun dan kapanpun oleh masyarakat.

Pertemuan kedua dilaksanakan pada tanggal 4 Agustus 2019 dihadiri oleh 29 orang peserta. Narasumber menyampaikan pentingnya kecakapan berkomunikasi berbasis kearifan lokal. Kecakapan berkomunikasi bisa dilestarikan dan digunakan pada saat berinteraksi dalam kehidupan bermasyarakat maupun kehidupan sosial lainnya. Kegiatan berkokomunikasi ini diharapkan juga ibu-ibu bisa mahir menggunakan bahasa Inggris dan bisa membuka lembaga-lembaga kursus yang dapat meningkatkan taraf ekonomi masyarakat. Kegiatan ini menjadi tolok ukur bagi masyarakat agar memiliki keterampilan berbahasa Inggris secara aktif sehingga berdampak positif kepada warga Kavling Seroja.

Bahan-bahan dan alat-alat yang sudah disediakan oleh tim pelaksana agar bisa digunakan saat di lapangan. Bahan-bahannya terdiri atas texapon, jeruk nipis, air mineral, garam, daun pandan. Alat-alat yang digunakan blender untuk melumatkan daun pandan sebagai pewarna alami, baskom, sarung tangan plastik, dan memanfaatkan botol minuman bekas yang masih layak pakai. Narasumber langsung menyampaikan jenis-jenis bahan yang dipakai beserta takaran yang diperlukan. Texapon sebagai pembuatan busa pada sabun. Daun pandan digunakan sebagai pewarna dan pewangi lamai dalam pembuatan sabun cuci piring. Garam sebagai pengental sabun cuci piring. Jeruk nipis sebagai pembersih, menghilangkan kuman, serta menghilangkan bau pada bahan tambahan sabun cuci piring. 1 kilo texapon bisa menghasilkan 10 liter sabun cuci piring yang siap pakai.

Hal-hal yang perlu untuk dihindari dalam berkegiatan wirausaha adalah (1) menghilangkan rasa malu, (2) takut gagal. Kegiatan belum dijalankan. Akhirnya tidak jadi dilaksanakan. (3) Tidak kompeten secara manajerial. (4) Tidak bisa mengolah dari hasil yang kita dapat dari hasil yang kita olah. (5) Memanfaatkan android untuk mencari peluang usaha yang bisa diterapkan oleh peserta pengabdian. Bisa mempromosikan melalui gawai dan sebagai alat komunikasi yang bisa dimanfaatkan. (6) Jangan sampai patah semangat. (7) Bisa memotivasi peserta pengabdian dalam mengendalikan keuangan enterpreneurship. (8) Mencari lokasi yang ramia dikunjungi oleh masyarakat. Untuk menghindari kegagalan dalam berwirausaha. Harus terus belajar. Mampu memanfaatkan teknologi informasi (Ramdhan, 2016).

Sebagai warga negara yang baik harus turut membudayakan dan mengutamakan bahasa Indonesia, melestarikan bahasa daerah, dan menguasai asing. Bahasa Indonesia sebagai bahasa yang memiliki martabat di mata dunia dan menjadi bahasa pengantar
ASEAN. Sebagai warga Kavling Seroja mereka turut bangga karena bahasa Indonesia snagat dihargai oleh bangsa lain. Narasumber tersebut juga menyampaikan bahasa daerah sebagai bahasa ibu juga harus turut dilesatraikan karena kalau bukan kita siapa lagi, kalau bukan sekarang kapan lagi. Kita tidak perlu malu dan gengsi mneggunakan bahasa daerah kita masingmasing. Bangkan bangsa lain sangat tertarik dengan kakayaan dan keanekaragaman bahasa daerah yang ada di Indonesia. Hal ini bertujuan agar bahasa daerah tidak punah. Di samping itu, untuk mengikuti arus globalisasi juga harus memahami dan menguasai bahasa asing terutama bahasa Inggris sebagai bahasa pengantar internasional.

Banyak cara bisa diwujudkan agar kita mampu menguasai bahasa Inggris. Dengan melakukan latihan tanpa rasa malu dan sungkan, penggunaaan bahasa Inggris bisa dilakukan secara lancar dan aktif. Narasumber memberikan motivasi dan menuntun peserta pengabdian agar terus berupaya menguasai bahasa Inggris terutama bahasa Inggris untuk pariwisata. Apabila mereka bertemu dengan turis mancanegara, peserta pengabdian bisa memberikan petunjuk dan informasi seputar informasi yang mereka perlukan.

Pertemuan ketiga dilaksanakan pada tanggal 10 Agustus 2019 dihadiri oleh 21 orang peserta. Narasumber menyampaikan bahwa pentingnya kecakapan dalam berkomunikasi. Kecakapan bahasa Inggris dengan bahasa Indonesia berbeda. Kecakapan berkomunikasi English for Tourism. Dari segi kecakapan berbahasa Inggris harus menggunakan norma kesopanan. Ungkapan yang dipakai dalam berkomunikasi English for Tourism berupa ungkapan menawarkan, ungkapan terima kasih, ungkapan minta maaf, ungkapan salam, dan ungkapan meminta sesuatu. Ungkapan untuk menawarkan kepada seseorang tentu menggunakan budaya yang santun. Selain itu, juga menggunkan katakata yang formal. Oleh karena itu, peserta pengabdian diajak untuk terus berupaya belajar dan mampu menggunakan bahasa Inggris secara fasih dan menggunakan pelafalan yang sesuai.

Kecakapan berkomunikasi English for Tourism juga harus menggunakan redaksional kalimat yang formal. Narasumber mempraktikkan langsung cara pelafalan dengan baik. Selanjutnya, peserta pengabdian mengikuti apa yang dilafalkan oleh narasumber. Narasumber yang diundang adalah mahasiswa program studi Sastra Inggris sekaligus mengaplikasikan ilmu yang mereka peroleh di tengah-tengah masyarakat. Pada ungkapan minta maaf juga harus digunakan secara santun menggunakan bahasa Inggris berbasis kearifan lokal. Peserta pengabdian juga aktif bertanya berdasarkan topik yang disampaikan sehingga kegiatan lebih hangat dan tepat sasaran karena masyarakat mengerti apa yang akan mereka ucapkan dalam berkomunikasi apabila bertemu dengan turis. Ungkapan permintaan atau meminta sesuatu. Contoh yang disampaikan misalnya meminta secangkir kopi. 
Penggunaan kata can bagi orang luar negeri dianggap kurang sopan. Lebih sopan lagi menggunakan may atau could. Contoh may I get a cup coffee. Kegiatan selanjutnya diadakan diskusi dengan peserta pengabdian. Peserta menyampaikan argumen dan berdiskusi secara santun dengan narasumber.

Pertemuan keempat dilaksanakan pada tanggal 17 Agustus 2019 dihadiri oleh 21 orang dengan penyampaian materi English for Tourism sangat berdampak positif bagi peserta pengabdian. Faktor penunjang penyampaian materi English for Tourism karen kota Batam sudah menjadi kota pariwisata dengan menggalakkan situs-situs wisata dan cagar budaya yang ada di kota Batam. Narasumber menyampaikan tentang materi tentang memberikan petunjuk jalan jika bertemu dengan turis di lokasi wisata. Hal ini menjadi anutan bagi peserta pengabdian agar dapat menjawab pertanyaan dari turis jika bertanya sama mereka. Narasumber yang melibatkan mahasiswa memberikan petunjuk dengan kecakapan berkomunikasi secara tepat.

Setelah narasumber menjelaskan materi, pihak pelaksana meminta peserta pengabdian untuk mempraktikkan kemahiran berbahasa Inggrisnya seputar English for Tourism. Peserta pengabdian mengakui sering bertemu turis di pusat perbelanjaan dan di lokasi objek wisata. Awalnya mereka susah memahami dan menjawab pertanyaan turis tersebut menggunakan bahasa Inggris. Saat mempraktikkan tersebut, peserta yang diminta memahami dan mahir menggunakan English for Tourism secara perlahanlahan dengan lancar.

Pertemuan kelima dilaksanakan pada tanggal 25 Agustus 2019 dihadiri sebanyak 23 orang peserta. Kegiatan ini dihadiri oleh narasumber yang mampu membuat dan mempratikkan pembuatan keset kaki di hadapan peserta pengabdian. Kegiatan pengabdian kepada masyarakat ini mengajak masyarakat agar memiliki keterampilan dan usaha yang mandiri yang nantinya bisa membuka lapangan usaha, memperkerjakan ibu-ibu rumah tangga, serta mendirikan UMKM Kavling Seroja. Kegiatan ini tetap mendayagunakan dan corak nilai-nilai kearifan lokal yang ada.

Saat memulai kegiatan pembuatan keset kaki, narasumber memulai pembuatannya dengan menjelaskan tahap demi tahap. Alat yang digunakan bernama "mal" sebagai alat untuk merangkai keset kaki. Pembuatan keset kaki memanfaatkan kain-kain limbah dari hasil daur ulang suatu pabrik di Kota Batam yang tidak mereka gunakan lagi. Pembuatan keset kaki juga bertemukan ramah lingkungan dan membantu serta mendukung program pemerintah dalam hal go green. Awal mula menyampaikan bahan-bahan dan alat-alat yang digunakan.

Saat memulai kegiatan pembuatan keset kaki, narasumber memulai pembuatannya dengan menjelaskan tahap demi tahap. Alat yang digunakan bernama "mal" sebagai alat untuk merangkai keset kaki. Pembuatan keset kaki memanfaatkan kain-kain limbah dari hasil daur ulang suatu pabrik di Kota Batam yang tidak mereka gunakan lagi. Pembuatan keset kaki juga bertemukan ramah lingkungan dan membantu serta mendukung program pemerintah dalam hal go green. Awal mula menyampaikan bahan-bahan dan alat-alat yang digunakan.

Tim pelaksana dan peserta pengabdian membaur dalam menyaksikan percontohan dalam pembuatan keset kaki yang disajikan oleh narasumber. Narasumber menyampaikan dalam memadukan warna agar menarik dan memiliki nilai jual yang tinggi harus memadukan nilai-nilai estetika berbasis kearifan lokal. Selama 30 menit narasumber berhasil menyelesaikan satu buah keset kaki yang menarik tanpa meninggalkan nilai-nilai kearifan lokal yang disaksikan oleh puluhan peserta pengabdian. Awal mula kegiatannya merangkai dan menyusun motif kain dengan warna yang senada sehingga menarik minat orang untuk membeli. Setelah selesai merangkai menggunakan "mal", terakhir mengikat secara erat agar tidak mudah lepas dan tahan lama digunakan oleh konsumen. Terakhir proses perapian dengan menggunting bagian ujung keset kaki agar sama panjang. Akhirnya keset kaki tersebut dapat digunakan dan dipasarkan.

Setelah itu, peserta pengabdian belajar merangkai kesert kaki atas panduan dan arahan dari narasumber. Mal yang disiapkan sekitar tujuh alat sehingga peserta pengabdian bisa secara bergantian mempraktikkan pembuatan keset kaki tersebut. Ada yang kesulitan memadukan warna, ada peserta pengabdian yang kurang kuat saat mengikat satu sama lain, bahkan ada yang kesulitan dalam menjalin kain demi kain. Ini adalah proses awal pembelajaran bagi peserta agar terus giat sehingga bisa menghasilkan keset kaki yang bisa dijual di pasaran antara harga Rp 15.000,00 s.d. Rp 25.000,00. Padahal modal untuk satu keset hanya memerlukan modal Rp 5.000,00/keset kaki karena memanfaatkan perca-perca kain dari industri kain yang ada di Kota Batam.

Dengan adanya kegiatan ini sangat membawa manfaat bagi masyarakat Kavling Seroja. Dari hasil kegiatan mereka dan pihak mitra merasakan dampak yang sangat memuaskan. Masyarakat mahir berbahasa Inggris apabila berjumpa dengan turis atau bahkan bisa menjadi guide atau pemandu wisata di Kota Batam. Selain itu, ibu-ibu rumah tangga juga mempunyai keterampilan membuat keset kaki dan sabun cuci piring bebas zat kimia secara alami.

Dengan adanya kegiatan ini sangat membawa manfaat bagi masyarakat Kavling Seroja. Dari hasil kegiatan mereka dan pihak mitra merasakan dampak yang sangat memuaskan. Masyarakat mahir berbahasa Inggris apabila berjumpa dengan turis atau bahkan bisa menjadi guide atau pemandu wisata di Kota Batam. Selain itu, ibu-ibu rumah tangga juga membuka usaha secara mandiri untuk meningkatkan ekonomi. 


\subsection{Pembahasan}

Pengabdian kepada masyarakat menjadi tugas pokok tim pengabdi agar mendedikasikan diri dan ilmunya serta bermafaat bagi masyarakat. Tim pengabdi sekaligus menjadi narsumber dan juga mengundang narasumber sesuai dengan bidang keahlian agar bisa dipraktikkan di tengah-tengah peserta pengabdian.

Permasalahan yang ditemukan saat survei, wawancara dengan pihak RW dan masyarakat setempat saat mengunjungi lokasi pengabdian dapat dijabarkan sebagai berikut. Berdasarkan permasalahan tersebut dilakukan pembahasan kegiatan pengabdian kepada masayarakat stimulus kecakapan berkomunikasi berbasis english for tourism dan enterpreneurship bermuatan kearifan lokal masyarakat Kavling Seroja Kota Batam.

Pertama, masyarakat belum mahir menggunakan bahasa Inggris. Padahal daerah di sekitar tempat tinggal masyarakat berpotensi untuk dikunjungi oleh turis. Hal tersebut menjadi kendala bagi mereka dalam mengembangkan diri dan melayani turis yang datang. Berdasarkan permasalahan tersebut, tim pengabdi berupaya untuk memberikan pengetahuan kepada masyarakat agar mahir berbahasa Inggris dan bisa mengelola bidang pariwisata di dekat tempat tinggalnya.

Saat proses pelaksanaan kegiatan pengabdian masyarakat yang dilasanakan selama lima kali pertemuan dan dihadiri oleh narasumber, mitra, dan melibatkan mahasiswa sangat membawa manfaat kepada peserta pengabdian. Hal ini dibuktikan dengan adanya semangat peserta pengabdian untuk terus hadir setiap kali pertemuan, mendengarkan dan menyaksikan secara seksama tentang materi english for tourism yang disampaikan narasumber.

Lokasi mitra juga sangat dekat dengan destinasi wisata yang sering dikunjungi oleh turis mancanegara sehingga tim pengabdi memiliki tanggung jawab agar masyarakat sekitar mahir berbahasa Inggris untuk pariwisata. Hal ini menjawab permasalahan yang ditemukan saat sebelum pelaksanaan kegiatan pengabdian kepada masyarakat sebelumnya. Selain itu, dengan adanya kegiatan pengabdian ini juga mampu meningkatkan perekonomian masyarakat setempat dengan memiliki profesi tambahan menjadi guide, membuka lembaga kursus, dan menjadi agen untuk membuka lapangan pekerjaan dalam memperkerjakan masyarakat setempat menjadi pemandu wisata yang kreatif dan menarik turis yang berkunjung.

Penyampaian materi English for tourism juga berbasis nilai-nilai kearifan lokal. Walaupun peserta pengabdian berasal dari daerah yang berbeda-beda. Namun, tidak menyurutkan semangat peserta pengabdian untuk terus berupaya dan belajar agar mahir menggunakan bahasa Inggris untuk pariwisata. Kemampuan hanya ada pada masing-masing peserta pengabdian. Sebenarnya, peserta pengabdian memiliki potensi untuk mahir berbahasa Inggris. Tim pengabdi terus mengajak, memotivasi, dan memberikan materi secara ringkas agar mudah diphamitdan dipraktikkan oleh peserta pengabdian.

Selain itu, pemerintah juga turut menggalakkan perbaikan dan pembangunan infrastruktur. Infrastruktur juga menjadi instrumen pendukung dalam kegiatan English for tourism. Jika infrastruktur semakin bagus dan fasilitas sangat memadai akan menarik turis untuk berkunjung sehingga juga menambah pendapatan masyarakat untuk bisa membuka lapangan usaha atau enterpreneurship.

Peserta pengabdian diberikan pelatihan English for Tourism. Pelatihan English for Tourism bisa dimanfaatkan peserta karena sudah mahir menggunkan bahasa Inggris untuk pariwisata bisa menjadi guide atau pemandu wisata yang bernilai kearifan lokal. Saat hari libur tahunan atau libur nasional mereka bisa mendatangi lokasi-lokasi wisata yang dikunjungi oleh banyak turis atau bergabung dengan agen tour and travel yang menjamur di Kota Batam sehingga mereka memiliki penghasilan tambahan secara produktif. Selama kegiatan berlangsung, peserta pengabdian memiliki kemauan secara mandiri untuk bisa menguasai bahasa Inggris secara aktif. Saat diminta ke depan oleh tim pengabdi, mereka dengan hati dan bersedia mempraktikkan ilmu-ilmu yang mereka dapatkan saat kegiatan pengabdian berlangsung.

Relevan dengan permasalahan yang dikemukakan, pembahasan akan dijabarkan sebagai berikut. Pertama, masyarakat setempat belum memiliki kemahiran dalam mengelola aset dan talenta yang dimiliki untuk bisa dijadikan sebagai usaha enterpreneur yang kreatif. Padahal menjadi peluang besar bagi masyarakat dalam meningkatkan taraf perekonomian keluarganya. Kegiatan pengabdian menjawab dan memberikan solusi dari permasalahan yang ditemukan. Sebagai kota berbasis pariwisata, Kota Batam banyak menawarkan peluang besar dalam mengelola aset yang menghasilkan sumber ekonomi. Selama kegiatan pengabdian berlangsung, tim pengabdi mengajak dan merangkul peserta agar mampu mengelola aset yang ada di sekitar kehidupan mereka. Peserta mampu memanfaatkan halhal yang bisa jadi peluang untuk membuka usaha enterpreneur berbasis kearifan lokal.

Dalam kegiatan pengabdian ini merancang kegiatan pelatihan pembuatan keset kaki. Batam sebagai kota industri memiliki industri tekstil yang bisa memanfaatkan perca-perca kain atau disebut limbah kain yang bisa dimanfaatkan untuk pembuatan keset kaki yang bermotif dan menarik. Hal ini menjadi kesempatan dan peluang usaha enterpreneur bagi masyarakat setempat sehingga bisa diolah jadi keset kain, lap tangan, lap pembersih mobil dan motor, bahkan perca kainnya bisa dijadikan sebagai selimut yang bernilai jual dan kreatif. Melalui kegiatan ini membuat masyarakat bisa merenung dan mengkreasikan nilai-nilai kearifan lokal menjadi rupiah. 
Tentu kegiatan ini sangat membantu pemerintah dalam menggiatkan masyarakat agar memiliki usaha enterpreneur yang mandiri dan menghasilkan.

Kedua, masyarakat yang khususnya ibu-ibu rumah tangga belum memiliki jiwa kreatif untuk membuka usaha berdasarkan keahlian dan keterampilan yang dimilikinya. Padahal, berdasarkan hasil survei dan wawancara ke lokasi pengabdian, masyarakat tersebut mengakui pandai membuat kue, snack, cemilan, maupun keahlian menjahit, keset kaki, dan keahlian lainnya. Padahal itu menjadi aset bagi mereka untuk bisa maju dan berkembang di bagian wirausaha. Namun, dalma kegiatan pengabdian ini akan mengoptimalisasikan pembuatan keset kaki secara kreatif dan bernilai jual.

Tim pengabdi memberikan solusi cerdas dalam mensinergikan bahwa kegiatan berwirausaha, yaitu (1) peserta pengabdian mampu menciptakan peluang, (2) bangkit dalam keterpurukan, (3) tidak suka jadi bawahan atau tidak suka disuruh-suruh, dan (4) memiliki lingkungan keluarga atau teman-teman yang sudah sukses dalam kegiatan enterpreneurship.

Ketiga, masih minimnya peranan pihak terkait dan memiliki wewenang dalam mengembangkan kearifan lokal di Kota Batam. Kearifan lokal menjadi ciri khas budaya Melayu di Kota Batam. Kota Batam yang terkenal dengan ikon jembatan barelang dan destinasi Welcome to Batam menjadi daya tarik untuk turis berkunjung dan berdomisili di Kota Batam. Di samping itu, negeri berpancang amanah bersauh marwah juga kaya akan kuliner khas Melayu yang bisa dijadikan sebagai lahan usaha yang sangat menjanjikan. Kesempatan dan peluang sangat terbuka lebar bagi peserta pengabdian yang rata-rata memiliki keahlian dan keterampilan dalam mengolah makanan yang bercita rasa tinggi artinya bisa membuka usaha enterpreneur dengan memperkerjakan masyarakat sekitar sebagai karyawannya.

Walaupun minimnya peranan pihak terkait, tetapi mitra sangat mendukung dan merespons kegiatan ini. Pada kegiatan sebelumnya belum ada yang melaksanakan yang serupa dengan tim pengabdi. Bahkan kalau pun ada, warga tidak ada yang berdatangan ke lokasi kegiatan dengan berbagai macam alasan. Namun, pada saat kegiatan pengabdian yang dilaksanakan oleh tim pengabdi, banyak masyarakat sebagai peserta pengabdian yang berdatangan dari pertemuan awal hingga selesai. Ternyata kegiatan ini sangat menarik bagi masyarakat karena membuka awasan mereka agar bangkit dari keterpurukan ekonomi yang selama ini hanya mengandalkan pemasukan dari suami.

Keempat, optimalisasi kearifan lokal belum dilaksanakan secara maksimal dalam masyarakat. Hal ini ditunjukkan sarana yang dimiliki belum mampu memiliki dan mengelola kearifan lokal. Awal mula masyarakat belum menyadari nilai-nilai kearifan lokal yang ada di Kota Batam. Mereka belum memanfaatkan dan mengintegrasikan nilai-nilai kearifan lokal tersebut dalam dunia enterpreneur. Selama kegiatan ini berlangsung, barulah mereka menyadari bahwa banyak kekayaan nilai-nilai kearifan lokal yang bisa diolah dan mendatangkan tambahan in come rumah tangga.

Kelima, kreativitas masyarakat dalam mengelola dan mengembangkan aset daerah tempat tinggal masih terbatas. Oleh karena itu, diperlukan kegiatan pembinaan yang bertujuan untuk mengarahkan dan membina masyarakat setempat untuk bisa mandiri dan kreatif. Saat melihat urgensi dari kegiatan pengabdian kepada masyarakat ini mengajak dan mengubah pola pikir masyarakat agar mampu mengolah dan memberdayakan potensi sumber daya manusia yang ada secara optimal. Kegiatan pengabdian kepada masyarakat ini megembangkan aset dan kreativitas yang ada di sekitar lingkungan peserta pengabdian.

Keenam, masyarakat juga terkendala dengan dana untuk memulai usaha UMKM. Hal ini menjadi urgen demi terlaksananya kegiatan entreprenuer agar bisa berkembang di tengah masyarakat serta bisa mendayagunakan potensi sumber daya manusia yang ada. Saat survei dan pelaksanaan kegiatan pengabdian masyarakat di Kavling Seroja, masyarakat juga mengeluhkan memulai dana awal dalam membuka UMKM. Setelah kegiatan pengabdian kepada masyarakat, UMKM di Kavling Seroja dibuka dan diberikan izin oleh pihak RW setempat. Dari dana talangan awal masing-masing peserta, akhirnya persoalan dana mulai teratasi. Di samping itu, UMKM tersebut jug berencana mengajukan dana pinjaman usaha mikro kepada bank agar usaha mereka semakin berkembang. Mereka juga mengupayakan agar melengkapi persyaratan yang memadai.

Inovasi dalam kegiatan pengabdian kepada masyarakat ini adalah (1) Masyarakat Kavling Seroja memiliki kemahiran english for tourism setelah kegiatan PKM dilaksanakan. (2) Masyarakat Kavling Seroja memiliki keterampilan membuat sabun cuci piring bebas zat kimia yang bisa dijadikan lahan enterpreneurship. (3) Masyarakat memiliki keterampilan membuat keset kaki berbasis kearifan lokal. (4) Kavling Seroja memiliki UMKM pembuatan keset kaki secara kreatif dengan memanfaatkan limbah kain dan perca kain.

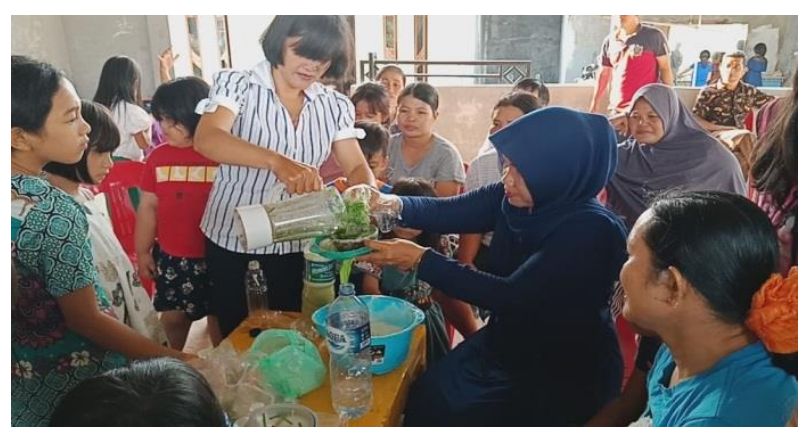



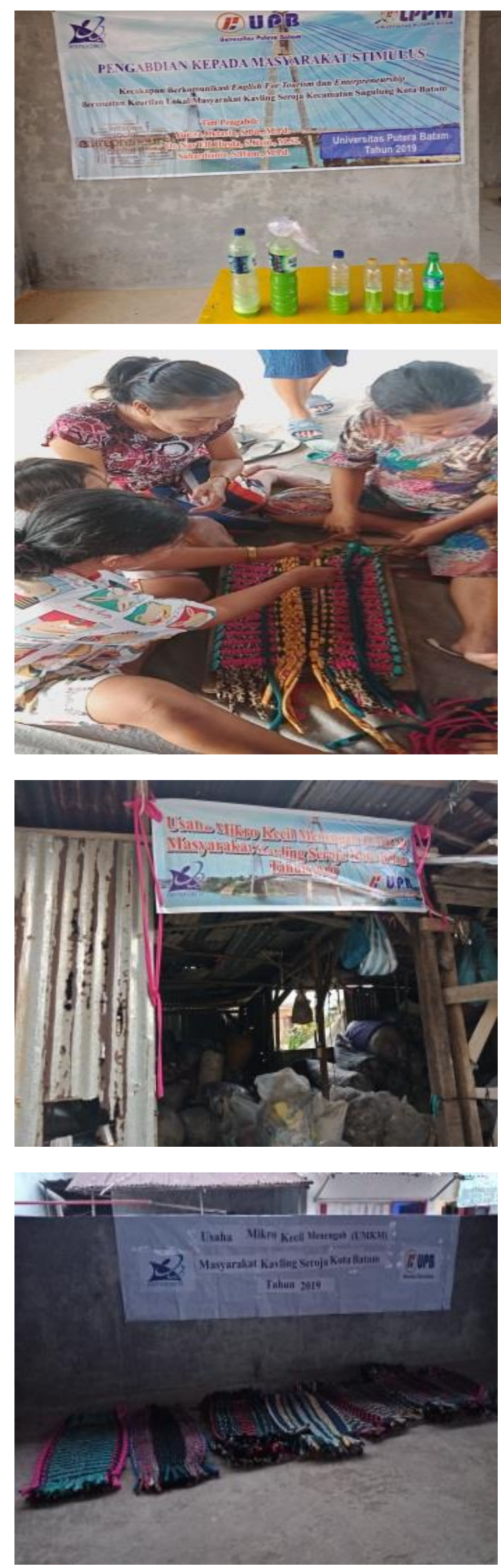

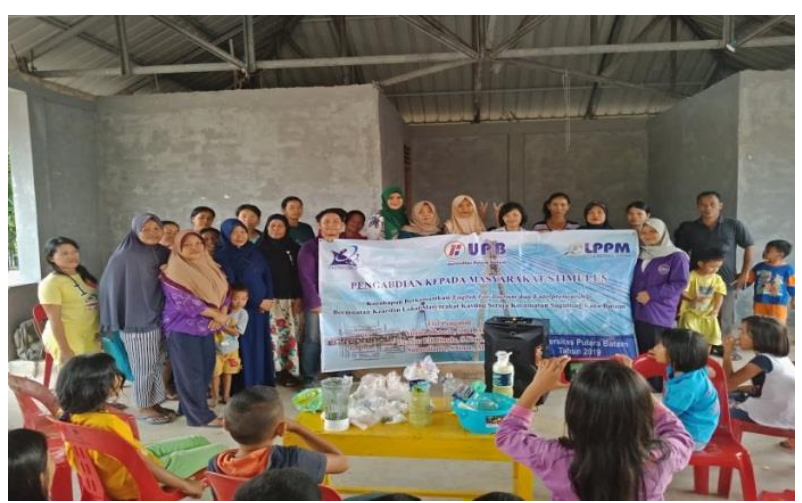

Gambar 1. Hasil Kegiatan Pengabdian kepada Masyarakat.

\section{KESIMPULAN}

Berdasarkan hasil kegiatan pengabdian kepada masyarakat dapat disimpulkan bahwa: (1) 17 orang peserta secara fasih dan 8 orang lagi belum lancar menggunkaan bahasa Inggris. Peserta pengabdian memiliki kecakapan berkomunikasi dalam keseharaian dengan mengutamakan etika berkomunikasi dan kesantunan. (2) Masyarakat keterampilan membuat sabun cuci piring sebanyak 15 botol satu hari dengan modal Rp 25.000,00 sehingga bisa terjual Rp 75.000,00. Modal satu keset kaki Rp 5.000,00 sehingga bisa terjual Rp 12.000,00 s.d. Rp 15.000,00 perlembar. Masyarakat bisa menghasilkan tiga sampai lima keset kaki dalam satu hari perwarga. (3) Masyarakat memiliki satu UMKM baru yang berada di Kavling Seroja sehingga bisa menghasilkan nilai ekonomi secara berkelanjutan.

\section{UCAPAN TERIMA KASIH}

Penulis mengucapkan terima kasih kepada DRPM Kemenristek Dikti yang sudah mendanai pelaksanaan kegiatan pengabdian kepada masyarakat stimulus ini pada tahun 2019. Penulis juga menyampaikan terima kasih kepada Universitas Putera Batam dan mitra beserta peserta PKMS di Kavling Seroja Kota Batam yang telah memberikan dukungan dan memfasilitasi terhadap kegiatan pengabdian kepada masyarakat stimulus ini.

\section{DAFTAR PUSTAKA}

Fajarini, U. (2014). Peranan Kearifan Lokal dalam Pendidikan Karakter. SOSIO DIDAKTIKA: Social Science Education Journal, 1(2). https://doi.org/10.15408/sd.v1i2.1225

Hastuti, D. (2013). Kearifan Lokal Sosial Budaya Masyarakat Minang Pedagang Rantau di Jakarta. In Proceeding PESAT (Psikologi, Ekonomi, Sastra, Arsitektur \& Teknik Sipil). Vol. 5 Oktober 2013. ISSN: 1858-2559.

Jeniarto. (2013). Diskursus Local Wisdom: Sebuah Peninjauan Persoalan-persoalan. Ltima Humaniora2, September.

Nugraha AR, Perbawasari S, Zubair F. Model Komunikasi Pariwisata Yang Berbasiskan Kearifan Lokal. The Messenger. 2017;9(2):23140. 
Oktavia, Y. dan, \& Hulu, F. (2017). Pengembangan Modul Ejaan Bahasa Indonesia Berbasis Pendekatan Contextual Teaching and Learning Bermuatan Pendidikan Karakter. Belajar Bahasa, 2(2), 250-265.

Oktavia, Y., Putra, E. E., \& Silalahi, M. (2019). Pembinaan Budaya Literasi Berbasis Android untuk Kemahiran Bahasa Inggris dan Kesantunan Berbahasa. Dinamisa, 3, 90-100.

Ramdhan, H. E. (2016). Starupreneur menjadi Enterpreneur Startup. Jakarta: Penebar Plus (Penebar Swadaya Grup).

Tölkes, C. (2018). Sustainability Communication in Tourism - a Literature Review. Tourism Management Perspectives, 27(April), 10-21. https://doi.org/10.1016/j.tmp.2018.04.002 